\title{
The changing social organization of prison protection markets: when prisoners choose to organize horizontally rather than vertically
}

\author{
R. V. Gundur ${ }^{1}$ \\ Published online: 28 February 2018 \\ (C) The Author(s) 2018. This article is an open access publication
}

\begin{abstract}
This article revisits the framework which Buentello et al. (Prison J 71(2): 3 $14,1991)$ created to describe the development of inmate solidarity groups into prison gangs in the Texas Department of Corrections. Interviews with current and former prison gang members in Texas, Arizona, and Illinois augment the current published literature on prison gangs in California. This article argues that the responses which prison administrations make to prisoners' social orders are not static and have, in some cases, caused vertically configured groups to evolve into horizontally configured groups. These structural changes in prison gangs affect the gangs' ability to affect control in the criminal underworld outside prison. Accordingly, although the challenges which prison administrations present to vertically developed social orders within prison may improve the administrations' control within the prison walls, they may effectively decrease criminal-led social control on the street, leading to an increase in street-level violence.
\end{abstract}

Keywords Prison gangs $\cdot$ Security threat groups $\cdot$ Social order $\cdot$ Protection rackets · Prisons · Organized crime

\section{Introduction}

To date, the majority of research undertaken, by academics and practitioners alike, on "prison gangs," formally known as "security threat groups," focuses on vertically organized groups (Buentello et al. 1991; Fleisher and Decker 2001; Fong 1990; Orlando-Morningstar 1997; Pyrooz et al. 2011; Skarbek 2014). The model of prison

R. V. Gundur

rajeev.gundur@oxon.org

1 Department of Sociology, Social Policy and Criminology, University of Liverpool, Liverpool, UK 
gang development proposed by Buentello et al. (1991) suggests that prisoners form inmate solidarity groups to provide support mechanisms that operate via collective action within the prison protection racket market and may (or may not) evolve into prison gangs which, in addition to solidarity between members, sometimes engage in criminal activities both within prisons and on the streets.

Drawing on extensive fieldwork in Texas, Arizona, and Illinois, this article builds upon the Buentello et al. (1991) framework by suggesting that three theoretical contestations to existing prisoner-run protection rackets in prison ought to be considered: full administrative intervention to reassert control over inmate life; protection monopoly breaking; and partial administrative intervention. The last of these contestations has resulted in horizontally configured prison gangs, an organization type that must be incorporated for an updated Buentello et al. (1991) model. By using collective behavior that avoids vertical organization, these horizontal gangs are arranged in a flatter and less formal manner compared to the traditional vertically organized groups. As "survival units" (Elias 1978), horizontal gangs continue to extract the benefits that were once enjoyed only by vertical gangs while minimizing prison authorities' ability to suppress them. Moreover, the rise of horizontal gangs appears to affect life beyond the prison walls, where it seems to be a destabilizing force in the social order of the street, which, historically, has been affected by the leadership of strong vertical gangs (Fleisher and Decker 2001; Skarbek 2014). In sum, this article theorizes that the responses prison administrators make to the social order that exists within medium- to high-security prisons in the United States with relatively high general populations affect the ability of prison gangs to influence the criminal underworld on the street.

This article proceeds as follows: first, it discusses the methodological considerations of accessing and evaluating prison gangs; second, it describes the protection market in prison and the actors who are involved in it; third, it examines the development and evolution of vertical organizations, using the Barrio Azteca prison gang as a representative example; fourth, it assesses shifts in control that can occur in the prison protection market; fifth, it illustrates the development and evolution of horizontal organizations, focusing on the Tango gangs of Texas and the People and Folks federations of Chicago; and, finally, it considers the implications the rise of horizontal organizations has for the social order of the underworld beyond prison walls.

\section{Methods}

This research was undertaken as part of a larger project that examined the role of Mexican drug trafficking organizations in the United States in three sites that were particularly targeted by alarmist rhetoric: The El Paso, Texas/ Ciudad Juárez, Chihuahua metropolitan area; Phoenix, Arizona; and Chicago, Illinois. Shortly after entering the field, however, it became apparent that prison gangs played a large role in the drug trade in the El Paso borderlands. Accordingly, I expanded the initial project to examine prison gangs in each site.

These sites are relevant to the study of prison gangs. El Paso is the home of Barrio Azteca, one of the most significant prison gangs in Texas, as well as Chuco Tango, which is one of the branches of the quickly emerging horizontally structured "tango" 
prison gangs (Tapia et al. 2014; Texas Department of Public Safety 2015). Arizona is a state with long established security threat groups that have a history of behaving violently (Fischer 2001). Chicago, Illinois, is a city with a long history of gangs, including the Gangster Disciples, the Vice Lords, the Black P. Stones, and the Latin Kings, among many others (Hagedorn 2006). By drawing on data from these three sites plus existing research on the California prison system, this article compares relatively large-populated prison systems with significant prison gangs. Moreover, it compares administrative (non)responses to prison gangs.

Gaining access to prisons can be a difficult endeavor (Skarbek 2014), with some of the most illuminating research coming from those who have either worked in prisons or been incarcerated (Buentello et al. 1991; Fong 1990; Fong and Buentello 1991; Irwin 1980). Rather than attempting to gain the views of prison personnel, due to difficulty in accessing them, I opted to develop a "history from below" (Thompson 1966), whereby I focused on the perspectives of those at the bottom of the social ladder in the context of prisons: the inmates.

To gain access to former prison inmates in the states of my field sites, I used traditional snowball and chain referral methods (Heckathorn 2002; Wright et al. 1992) whereby I identified or was introduced to gatekeepers by academics and practitioners who operated in my sites. The gatekeepers, often people who worked in harm reduction or violence mitigation, introduced me to potential respondents who were current and former prisoners and, usually, members or associates of prison gangs. In addition, I recruited three situational respondents, whom I met by frequenting places and interacting with people where I worked and lived. Twenty-one of the 23 people recruited and interviewed using these traditional methods self-identified as prison gang members or gang associates.

To broaden my sample, I used Craigslist, an online classified ads service, to recruit individuals who had been incarcerated in state prisons. (A full, detailed account of the methods employed is recounted elsewhere (Gundur 2017).) The use of the classified ads resulted in 39 respondents who self-identified themselves as former inmates, 28 of which self-identified as prison gang members. Thirty-seven of the 39 respondents did not know another respondent. Two of the 37 knew each other and had seen the ad while surfing online together. I further verified individuals' self-identifications by asking them technical questions relating to the inmate classification procedure they would have gone through as inmates (Decker et al. 2014). Thirty-three of these respondents self-identified as prison gang members or associates, with four (two women and two men) identifying themselves as nuetrons or solanos, that is neutral inmates. Additionally, I avoided the risks of having respondents being coached for the remuneration offered, as experienced by Cromwell and Olson (1991), by avoiding chains longer than two links and by prioritizing varied recruitment rather than relying on the same sites and groups.

In total, I interviewed 64 individuals, seven women and $57 \mathrm{men}$, who had been incarcerated in a prison setting in Texas, Arizona, Illinois, California, and Chihuahua, Mexico. The respondents represented different gangs, neighborhoods, and social circles, with at least 20 street gangs and 12 prison gangs represented among the sample. Additionally, all inmates had served time in local county jails and state prisons; a minority had also served time in federal prisons. Accordingly, this research looks at jails and state prisons only. Moreover, given the relative lack of women in the sample $(n=7)$, I am not comfortable extending the analysis of this article to women's prisons in 
these sites. Consequently, this article focuses on the US experiences of men's prisons and prison social order, and therefore relies on the accounts of a subset of 53 men who had served time in Texas, Arizona, Illinois, and California. Of these $53 \mathrm{men}, 51$ of them had served time in medium security settings or above, up to and including solitary confinement, and reported either participating directly in or being subjected to inmate prison politics. Table 1 shows a breakdown of recruitment type and race by location.

All quotations used within this article are representative of views expressed by a plurality of the inmates of the represented geographical region.

Thirteen of the 16 respondents in El Paso were Hispanic, which is consistent with the demographics of the area which is $82 \%$ Hispanic (U.S. Census Bureau 2016). Comparing response rates to prison demographics is unhelpful because, overall, whites, African Americans, and Hispanics represent approximately equal proportions of inmates in Texas (Texas Department of Criminal Justice 2017). However, given El Paso's demographics, it likely sends more Hispanics than other ethnic groups to prison.

Twelve of the 18 respondents in Phoenix were Hispanic; three were white; three were black, and one was Native American. This sample over-represents Hispanic inmates, in comparison to prison proportions (40:40:14:6; Hispanic: African American: White: Native American), but reflects prison gang membership rates (Arizona Criminal Justice Commission 2016; Arizona Department of Corrections 2017).

Chicago respondents included a significantly higher proportion of African American respondents - nine of the 17 respondents - which again echoes the state's inmate demographics, where $57 \%$ of the prison population is African American while $30 \%$ is white and $13 \%$ is Hispanic (The Illinois Department of Corrections 2017).

Across the whole sample, the majority of gangs surveyed had primarily Hispanic membership. Accordingly, the patterns of behavior and organization are not necessarily generalizable to other ethnic gangs, though similarities did exist between the Tangos, the horizontally configured gangs in Texas, and the Chicago gangs, which did not always share the same racial and ethnic make-up. Additionally, this research focuses on states with relatively large prisons and prison populations, meaning that it makes no claim to describe dynamics in states not surveyed, particularly those with smaller and less diverse populations. It is fundamentally a study of context and may not be transferable to other contexts but provides a basis on how researchers might examine similar phenomena in divergent contexts (Edwards and Hughes 2005; Sampson 2012).

Overall, this research surveyed individuals who had been convicted of different crimes, served time in different prisons, were incarcerated at different times (from the late 1970s through 2013) and for varying lengths of time, were part of different social

Table 1 Demographics of respondents who served time in medium security carceral settings and methods of their recruitment

\begin{tabular}{lllllll}
\hline & Online & Traditional & Hispanic & White & African-American & Other \\
\hline Texas $(n=16)$ & 8 & 8 & 13 & 3 & 0 & 0 \\
Arizona $(n=18)$ & 8 & 10 & 12 & 3 & 2 & 1 \\
Chicago $(n=17)$ & 12 & 5 & 7 & 1 & 9 & 0 \\
Total $N=51$ & 28 & 23 & 32 & 7 & 11 & 1 \\
\hline
\end{tabular}


networks in and out of prison, and had different roles within those networks. The diversity of respondents allowed me to triangulate the data by comparing the claims made by my respondents against each other. In short, it became clear that the experiences regarding social control within medium and high security prisons were consistent within each state, with the overwhelming majority of respondents in each geographical location recounting similar processes, policies, and dynamics in their carceral narratives, though certain characteristics of social control within prison seemed to evolve over time and not necessarily in the same way in each context.

In addition to the former inmates, across the three sites, I interviewed 15 members of law enforcement, who had specific knowledge of the involvement security threat groups had in the street and the impact of prison bosses on street politics. The accounts these individuals provided, generally, supported the accounts given by the former inmates. In addition, I have drawn on published research on the California prison system (Dooley et al. 2014; Irwin 1980; Skarbek 2010, 2011, 2014; Trammell 2012). All respondents have been anonymized except for the late José Raúl Rivera Fierro, whose role as the founder of the Barrio Azteca prison gang made anonymizing him not possible. Rivera's quotes within are from extensive interviews with the author preceding his death.

\section{Prison protection markets}

\section{The evolution of inmate solidarity groups}

As every former inmate who had served time in a medium security prison or higher told me, it is impossible to avoid the "politics" of prison, by which they mean the social control regimes established by the inmates themselves and not by the prison administration. Upon entry, modern day inmates have three options: remain neutral, that is, in prisoner parlance, become a neutron or a solano, which obligates them to respect the social order while having few, if any, collective benefits from it; find religion, which allows them to follow their God and not be obligated to do anything considered immoral, such as fighting or breaking prison regulations; or, most commonly, become part of inmate society by joining a group that promises to underwrite their rights vis-àvis other inmates, while obligating its members to behave in accordance to the rules of the organization. Whatever option inmates choose, they are socialized into the cultural expectations of prison, that is the "convict code" (Trammell 2012). The development of inmate groups within the prison protection market is first systematically described in the literature by Buentello et al. (1991, p. 7), whose framework explains the organizational evolution that solidarity groups take in order to become security threat groups.

According to the Buentello et al. model of the evolutionary process of inmate solidarity groups, after entering prison, new inmates may join a "clique," which is essentially a friendship group that provides the inmates with a sense of belonging without typically imposing any rules or requirements for membership. The relationships formed and fostered in cliques are the basis upon which members can further engage in collective behavior (Thrasher 1927 [1963]). In time, these cliques may evolve into "protection groups," which impose simple rules of membership with the primary goal of providing protection to their members, such as fending off attacks from 
other groups, coalescing during riots, or establishing rights for their members vis-à-vis the other inmates. Small scale cliques may escape the gaze of prison staff; however, prison staff may identify protection groups as potential threats. Later, protection groups may evolve into "predator groups," with increased barriers to entry. These groups are willing to use violence to underwrite or expand their market share of the protection market and exhibit strong, though informal, leadership. Finally, predator groups may evolve into full-fledged "prison gangs," which have formalized rules, defined goals, hierarchical leadership, and lifelong membership. At every intermediate stage of the model, Buentello et al. state that a group can either maintain its status or disband.

The Buentello et al. model is an accurate description of the evolution of prison gangs as observed through the late 1990s in Texas and likely echoes the formation of prisoner social orders in prison systems with large general populations in the United States and possibly elsewhere. To an extent, the Buentello et al. model also describes the historical development of inmate groups in Illinois. However, it needs to be corrected to reflect that, generally speaking, while intermediate inmate solidarity groups typically exist only within a specific prison, prison gangs have a systemic existence throughout the state penitentiary system. Prison gangs are not merely an organization with a unitary presence but an organization with a networked presence that expands to other prisons and the free world. Additionally, the model needs to be revisited because it neither explains the circumstances which encourage the initial formation of vertical groups nor predicts the state interdictions of vertical leadership.

Members of the public may assume that the state maintains effective control over inmates' social affairs within the walls of a jail or prison. ${ }^{1}$ However, this notion has been historically tenuous in large prison systems, such as those of California and Texas. In the California and Texas prison systems, inmates created and managed their own social control regimes within their prisons, often with the implicit or explicit encouragement of the prison administration, who effectively cede control over the majority of the internal affairs of inmates (Dilulio 1990; Irwin 1980; Skarbek 2014), thus allowing the inmates to dictate the terms of the protection racket market within the prison walls.

\section{The birth of the prison protection racket: The California and Texas examples}

The contemporary protection racket market within prisons has its roots in the racial tensions that characterized American society for much of the twentieth century (and, to some extent, still characterizes American inmate society). Former inmate John Irwin describes the institutional racism present in the California prison system in the 1940s and 50s, the "Big House Era," when nonwhite inmates were "kept in their place" by white inmates and white prison guards (Irwin 1980, p. 9), thus maintaining the social order and control regime as desired by the prison administrators (Dilulio 1990). In the 1960s and 70s, Texas likewise had an inmate-managed control regime. However, this system was not predicated upon race. Instead, in the Texan "building tender system," prison administrators recruited intimidating inmates and allocated control of certain

\footnotetext{
${ }^{1}$ Jail refers to a county lockup where individuals are held upon arrest, on remand, and for short sentences. Prison refers to state or federal lockup where individuals are held upon sentencing of a crime, typically longer than 12 months. The developments described within this article occurred in state prisons, except where otherwise noted.
} 
areas of the prison to each (DiIulio 1990; Ekland-Olson 1986). These inmate guards became known as "turnkeys" because they literally had the keys needed to open and close the cell and corridor doors of the prisons.

Inmate-based social control regimes allowed prison administrators to keep relatively small guard staffs, while still having a degree of social control within the prison walls, even if prison administration staff did not directly administer the conditions of that control (Ekland-Olson 1986; Irwin 1980; Marquart and Crouch 1984). Moreover, prison administrators allowed prison governance, that is the provision of protection and services (Fukuyama 2013), to be managed by the inmates themselves. The white inmates of California's Big House Era and the turnkeys of Texas' Building Tender Era made and enforced the rules of day-to-day governance of the prison. Prison administrators were relatively hands-off, thus allowing these privileged inmates to establish and enforce their own norms. This arrangement allowed for the prison administrationfavored inmate groups to enjoy a virtual monopoly in the protection markets in prisons.

However, over time, these monopolies were challenged and broken. In California, starting in the 1950s, the nonwhite inmate population began to increase significantly (Irwin 1980). In turn, these nonwhite inmates began to unify themselves along selfsegregated identity groups, typically by geographic origin and/or race, as a means to contest the white dominance within the prison. The resulting groups of black, Chicano, and Tejano inmates enjoyed the advantages of collective action by forming solidarity groups that allowed them to nudge into the protection market of the California prison system (Irwin 1980).

The most notable California-based groups which were formed in the mid to late 1950s and which still exist today include the Mexican Mafia, made up of southern Californian Chicanos; la Nuestra Familia, made up of northern Californian Chicanos; and the Texas Syndicate (TS), made up of Tejanos (Hunt et al. 1993; OrlandoMorningstar 1997). The 1960s saw the rise of the Black Guerrilla Family as well as the Arian Brotherhood in the California prison system (Hunt et al. 1993). The formation of these two groups indicates that the prison protection market in California was contestable at the time: within the prison system, no monopoly on protection, whether by the prison administration or an inmate organization, existed.

The Texas prison system, unlike California, did have a monopoly in the protection market via the turnkeys. But that ended in 1981 when United States District Court Judge William Wayne Justice declared the building tender system in Texas illegal. Judge Justice gave Texas two years in which to find an alternative to the tender system (Justice 1981). Since the prison administration was woefully underprepared to reassert control without the aid of the inmate guards, an intensely competitive protection market within the prisons emerged and gave rise to several new security threat groups (Fong 1990). However, the organizations which emerged in both California and Texas did not immediately become mature prison gangs. The ability of an inmate solidarity group to develop a market share within the protection market that is large enough to engage in the governance processes of a prison is not immediately achievable.

Nonetheless, the circumstances that allowed these solidarity groups to form were similar and are likely to echo similar developments of prisoner solidarity groups in other large penitentiary systems: the monopolies of the previous dominant holders of protection were broken, and the state did not or could not fill that gap efficiently, thus allowing the prison's protection racket market to become newly competitive. It is 
notable that, at this time, neither the prison administration nor any existing groups had sufficient control within the protection market to prevent new prisoner solidarity groups from forming. As a result, vertical organizations emerged. Leaders organized and led their peers in collective action designed to contest threats they might face from the prison administration or other prisoners. Using their position at the top, founding leaders nearly always instituted a hierarchical command structure, with leadership to be replaced via promotion from the ranks below (Fleisher and Decker 2001).

\section{Voids in the protection market: 1980s Texas as an example}

Judge Justice's decision that rendered the building tender system unlawful created a control deficit for prison administrators since the turnkeys could no longer fulfil the security guard role. Moreover, without the turnkeys, the Texas Department of Corrections (TDC) lost the insider intelligence that allowed them to monitor prison developments (Fong 1990). In addition, the security staff shortages were compounded by the inexperience of the newly hired guards who did not know how to control the inmates effectively; both inmates and guards felt that the balance of power, or the ability to affect control within the prison walls, had shifted into the inmate's favor (Ekland-Olson 1986).

"As soon as [... the TDC] had to get rid of the building tenders, it caught the Prison Administration with their pants down because they weren't expecting it. [...] During that transition period, all hell broke loose," José Rivera Fierro recalled. "It started in 1983. It [continued for] about two years. [The TDC] had to train a bunch of guards. [...] They just needed bodies in uniform. They were inexperienced [and] guards were getting beat up."

The inability of prison administrators or the existing inmate groups to control the inmate population was evident in 1984 and 1985 when inmate homicides, the majority of which were gang related (Fong 1990), were at a rate that "was well ahead of all other [prison] systems [and] more than double the number (twelve) of the previous two high years, 1981 and 1982" (Burman 2012; Ekland-Olson 1986, p. 392). The lack of effective control also provided an opening for new solidarity groups to form without facing consequences from the existing order.

Though the Texas Syndicate existed long before this turmoil began, it did not effectively fill the control void left by the dissolution of the building tender system. The first Hispanic group to appear after the TS in the 1980s was the (Texas) Mexican Mafia, also referred to as the Mexikanemi or the Eme, not to be confused with organizations in California, Arizona, and elsewhere that bear the same name (Texas Department of Public Safety 2007). According to Rivera Fierro, the Eme and the TS initially coexisted. As the prison system transitioned out of the building tender system, instability in the social order of the prison systems developed. Consequently, Hispanics needed unity amongst themselves to counter black inmates, with whom they had frequent conflicts.

By 1985, within the Texas prison system, at least eight security threat groups existed, each formed along racial and ethnic lines and each with a hierarchical structure (Fong 1990); together, along with a now more experienced prison staff, the prison gangs re-established an effective social order within the prison walls. This order remained throughout the latter half of the decade. As a result, the chaotic scenes of 
inter-racial conflict that characterized 1983, 1984, and 1985 dissipated. However, the peace between the Eme and the TS ended in 1985 when a dispute over the prison drug trade triggered a war between the two groups.

"The Texas Syndicate went to the [upstart] Mexican Mafia at the Darrington Unit [where the Eme were selling marihuana to the other inmates] and told them, 'You know what? We want a cut. You got to pay taxes," Rivera Fierro recalled. "Now, the TS thought [the Eme would] be scared of them, that they were just going to lay down. But the Eme were no punks either. They were standup, too; they were somebody to be reckoned with."

Violence escalated between the Eme and the TS, now two of the largest inmate groups, which behaved as the prison gangs of the Buentello et al. model. This growth brought them the unwanted attention of the prison administration. The prison guards responded by isolating everyone they could identify as leaders of those organizations into administrative segregation (Fleisher and Decker 2001). With leadership and membership reduced in numbers, both the TS and the Eme needed to recruit new followers who would replenish the ranks and strive to dominate the Texas penitentiary system amongst Hispanic inmates. In their efforts to recruit, both the TS and the Eme relaxed their entry requirements. For their part, the boys of El Paso, including José Rivera Fierro, who was serving his time in the Coffield Unit, remained mostly neutral, respecting each organization, in part because they had friends in both. Eventually, the TS and the Eme, in an effort to coerce participation in their groups, began to ask the El Pasoans to pick a side.

\section{The birth of an inmate solidarity group and its evolution into a prison gang: The barrio Azteca}

The idea to start a carrucha, "a ride," an inmate group specifically for the El Paso and Juárez inmates, occurred to José Rivera Fierro while talking with his friend Benny Acosta. Neither Rivera Fierro nor his fellow El Pasoans wanted to be part of the bloodbath emerging between the Eme and the TS, so Rivera Fierro decided to formalize an organization which would provide an organizational structure, other than the established Hispanic prison gangs, that El Paso and Juárez inmates could join. The El Paso and Juárez inmates had good relationships among themselves because their two cities are one metropolitan area separated by an international border. Moreover, many of them had families on either side of that border and shared a cultural history. A structured organization would preclude other groups from recruiting El Paso and Juárez inmates.

The diminutive Rivera Fierro, a self-described goof and, at the time, drug addict, was well liked by his peers. Consequently, in 1984, when he summoned his fellow El Paso and Juárez inmates to a brief meeting, he was able to establish the Barrio Azteca, initially a solidarity group with a rough hierarchical order, with himself at the top and four or five captains beneath him. The other members were "put on the ride" as "soldiers," emulating the structure of the other established inmate organizations in prison. To that end, it was racially exclusive, meaning that only Hispanic inmates could join, respecting the long-standing racial order of prison. Yet, "there was no blood in, blood out [to join]," Rivera Fierro explained. Membership was informal: "There was just, yeah, 'I'm in the gang,' just by saying it." Rivera Fierro described the initial 
objectives of Barrio Azteca as twofold. First, Barrio Azteca would provide solidarity for the new Hispanic inmates from El Paso and Juárez by sharing hygiene products and introducing them to the norms of prison upon entering the prison system. Second, Barrio Azteca would ensure that the group would not coerced to be part of or be victimized by the other prison gangs.

Respondents from the El Paso Police Department and the El Paso DEA both identified Barrio Azteca as existing as a "prison gang" from 1987; however, from Rivera Fierro's account, it appears that Barrio Azteca formed as a solidarity group at least two years prior to that date, echoing the evolution as suggested by Buentello et al. (1991). Over the course of approximately five years, Barrio Azteca slowly evolved into a predatory group that preyed on other startup groups, such as the Mexicles which Rivera Fierro described as "an upstart [solidarity] group [made up of men from Juárez]. They formed because we alienated and shunned them when they wouldn't join [Barrio Azteca $]^{2 "}$. After Rivera Fierro was released from prison and ceased to be involved in the gang's leadership, the new leaders led Barrio Azteca to become a full-fledged prison gang that used its growing share of the protection market to expand its illicit enterprise into running protection and drugs in the free world. The gang operated protection as a "shelter against danger," which functions as a double-edged commodity in that on is either part of a party that provides it or a danger because one is being extorted by that party (Tilly 1985).

Over the course of the next 15 years, Barrio Azteca became one of the most significant security threat groups in the Texas prison system. Until 2015, it was rated as a "tier one" organization, the likes of which "pose the greatest gang threat to Texas due to their relationships with Mexican cartels, large membership numbers, high levels of transnational criminal activity, and organizational effectiveness" (Texas Department of Public Safety 2014, p. 2; 2015).

According to former inmates, even though the gang did not dominate every prison in which it had a presence, Barrio Azteca was able to hold a strong position within prison politics throughout the Texas prison system. Respondents' accounts of Barrio Azteca's strength behind bars varied depending on the ratio of El Paso-based inmates in the prison where they were incarcerated. For instance, Luke, a man who had spent time in a prison dominated by south Texas inmates, recounted that, in his prison, although Barrio Azteca was not as powerful as the Eme and the Texas Syndicate, it was not completely overrun by those other security threat groups. To that end, Barrio Azteca performed well in prisons where its members were historically sent, thus allowing it to recruit and expand its membership throughout the Texas prison system, while creating a network. Along with its prison expansion, Barrio Azteca expanded its presence in the underworld in El Paso and Juárez.

\section{Politics of the free World's underworld}

Vertical prison gangs, like Barrio Azteca, are able to develop the necessary capital within prison that is required to control two additional arenas: county jails and the free world's underworld. Economist David Skarbek's $(2010,2011,2014)$ work looks at the

\footnotetext{
${ }^{2}$ The Mexicles later became Barrio Azteca's mortal enemies in the war that claimed the lives of thousands in Juárez (Bowden 2010).
} 
implications of prison politics on the street, principally in the Californian context. What my respondents recounted, in both Texas and Arizona, where vertical groups have been the norm for at least the past three decades, paralleled Skarbek's findings. In short, vertical groups have clear interests that expand to the street: the authority and control they maintain within prison are paramount given the likelihood that an offender or an offender's associate eventually will end up in prison and be subjected to the whims of the controlling groups in prison. To that end, it is clear that the prison protection market, while initially negotiated within prison walls, extends to the outside world where it aids released members not only to emulate organized criminal organizations but also to expand into other criminal enterprises (Fleisher and Decker 2001; Gambetta 1993; Reuter 1983).

Charlie, a gang sergeant for the El Paso Police Department, recounted how Barrio Azteca began to manage criminal entrepreneurship in El Paso, shortly after its first members were released from prison in the late 1980s:

[Once Barrio Azteca established a presence on the street, they started to open] up stores, or what they would call tiendas in Spanish. These were individuals or actual businesses that sell narcotics in the streets of El Paso, and they charge a tax, or what they call a cuota, [on dealers who want to be] selling within the Barrio Azteca turf. If these individuals refused to pay, there would be threats of violence, violence, or even the taking of property in lieu of money for them to start paying this cuota. If [the Barrio Azteca] succeeded in having these people pay this tax, the Barrio Azteca would in turn start supplying them with narcotics. They were bringing those narcotics in from Juarez, Mexico.

In addition to using the social and organizational capital developed within prison to advance criminal goals in the free world, the presence of the organization extended to the county jails. As a result, Barrio Azteca could institute certain rules of its own. For example, Barrio Azteca effectively curtailed drive-by shootings by issuing a standing "green light" or order which required that any person who entered jail on suspicion of a drive-by would be administered a beating. This rule, among others, was designed to minimize risk of capture by law enforcement, increase receipts, and entrench and expand criminal rackets.

\section{Shifting control in the protection market}

Challenges to a prison society's status quo and the organizations which underpin it may occur over time. This article theorizes that there are theoretically three types of control shifts that may occur: full administrative intervention; protection monopoly breaking; and partial administrative intervention. All shifts result in the dominant providers of protection within the carceral setting to reduce challenges to their position within the existing order.

\section{Full administrative intervention}

The first control shift type, full administrative intervention into the social order of prison, occurs when the prison administration successfully eliminates the inmate- 
controlled social order. A fully successful intervention would occur if the prison administration were to re-monopolize protection within the prison. Such a change could be imagined if, for example, in the unlikely event, a standard prison were converted into single cell administrative segregation units. No inmate solidarity groups would be allowed to exist. Without any known examples, it is difficult to predict what the effects on the streets could be, but it could be postulated that the streets would echo what occurs in a partial administrative intervention, which results in organizational decay in the free world, which we shall consider later.

\section{Monopoly breaking and splintering}

The second control shift type, monopoly breaking, occurs when the dominant holder of protection either loses or cedes control over the social control regime of the prison. The dominant holder may be the prison administration, as we have seen in the previous discussion of the Californian and Texan penitentiary systems, or an existing inmate group which cedes power to some group other than the prison administration. The monopoly may be lost either due to external pressures, such as Judge Justice's decree, or due to internal challenges, such as internal strife within an existing organization, resulting in an organization's splintering.

An example of splintering occurred in the early 1980s in the Arizona prison system when the Arizona Mexican Mafia faced internal challenges which led to the group's splintering into the "Old Eme" and the "New Eme" (Fischer 2001). To this day, the two organizations maintain enmity. However, both organizations maintained their vertically-organized leadership structures, which helped to ensure that startups could not take hold, and transplants, that is gangs that came into the system because members from other states were being incarcerated in Arizona, could not gain a foothold in the protection market. Nonetheless, according to multiple respondents, the New Eme came to dominate Hispanic prison life, causing the Old Eme to become a small organization, populated largely by older members who are serving long sentences, often in administrative segregation.

Today, the New Eme faces another split. Linus, a man who chose to stay unaffiliated while serving his time in prison, described the current state of affairs ${ }^{3}$ as follows:

The New Mexican Mafia, they put a stop to a lot of the Old Mexican Mafia rules and [no more raping and killing people in prison] was one of them. And a lot of the Old Mexican Mafia used to bully the youngsters. The youngsters took over. There's more youngsters than $\mathrm{OGs}^{4}$ now. So, these youngsters put a stop to it. There's a New Eme. They said, "No more." [...] Now the youngsters are bullying the OGs, you know; but in a certain way. They don't go around beating them up or nothing; but they let them know, "This is our shit. You kick back and you follow our rules."

\footnotetext{
3 To avoid confusion, I have kept Linus' quote unchanged. However, the Old Mexican Mafia he refers to is the New Mexican Mafia of ' 81 . The New Mexican Mafia, as Linus refers to it, is a faction that has split from the New Mexican Mafia of ' 81 .

${ }^{4}$ OGs are "Original Gangsters," sometimes referred to as veteranos (veterans), members who are regarded to be part of an older generation.
} 
In short, the status quo that had been established more than 30 years ago was being challenged from within the organization, threatening another split which would result in a new vertical organization, thereby repeating history.

These developments have affected the dynamics of the street as well. Lil G, a member of the New Eme, explained that high-ranking members (carnales) of the New Eme who were part of a different faction attempted to tax him in the free world: "Me and my uncle, we had our own dope house. But the other carnales, they tried to tax us. You know what I mean? But it didn't work. It didn't work. A couple of people got killed." Nevertheless, street violence has not escalated to massive proportions; instead, how drugs are sold has changed, making the business more anonymous and difficult to tax. Eddie, a member of the New Eme, described the currently favored drug delivery system and how street gangs are not even worth controlling anymore:

[Gangs are] dead, man. They're nothing. We [the New Eme] don't use them to sell drugs. They're not even left around to sell for us. [...] There's a driver system now. I will have a series of drivers who deliver for me. My drivers aren't going to know who I am. How does that happen? Let's say I know you and I trust you. Ok, I'm giving the drugs to you and then you know your cousin and you trust him. You give him the drugs and he delivers. He gets phone calls with directions. There are spots, they change. The directions would be, "Get the pick up at this spot and drop it off over there." That's how it would work for longer deliveries.

The driver's number would be changed every 2 months, maybe sooner.

In effect, ceteris paribus, splintering affects violence in the street, given the need to compete over territory and control over illicit enterprise. However, as the illicit market drives the utility of street gangs down and keeps drug dealing from public view, the capacity for rival factions to tax each other becomes diminished, due to the anonymization of the process, thus reducing the likelihood of violent street-level conflict.

\section{Partial administrative intervention and the opening for horizontal groups}

The third, and final, control shift type is the partial administrative intervention. This policy involves correctly identifying vertical prison gang leadership and placing these individuals into solitary confinement, as has been the case in Texas, where the prison administration targeted the leadership of vertical prison gangs like Barrio Azteca. Emiliano, a former soldier for Barrio Azteca, commented on this phenomenon:

[The prison administration targets all of] us - like [Barrio] Azteca, Mexican Mafia, [Texas] Syndicate, La Razon Ida, Pistoleros, all them - [the prison administrators] lock us up. So, it's only in the whole unit you probably have ten or fifteen members out in [general] population. The rest of us are locked down.

With its leadership in solitary confinement, the control that Barrio Azteca once exhibited in prisons and in jails diminished. Although he may have embellished the importance of his own gang, Bradley, a Gangster Disciple (GD), described the current control structure in terms recounted by several others: 
Barrio Azteca ain't shit in prison. They don't have nothing. They think they used to run the county jail, but they don't anymore. In the county jail here, it's segregated. You're Barrio Azteca out here, they're gonna put you in C Unit. Right now, Chuco Tango and GD run the Annex. They find out you're Barrio Azteca over in Sanchez, the state jail here, ooh-wee, I'm sorry to hear that! Actually, statewide across prisons, I've heard this time and time again - [if] you're Barrio Azteca, you're getting put in lockdown.

The targeting of gang leadership also occurred in Illinois, where prison officials managed to charge known prison gang leaders with Federal crimes and, upon winning convictions, transferred these individuals to a Federal facility where they serve what are effectively life sentences in solitary confinement. Such has been the case for former Chicago gang leaders Jeff Fort, Larry Hoover, Gino Colón, and Augustin Zambrano, among others, who have been convicted on Federal criminal charges.

Successful and consistent targeting of gang leadership results in the inability of vertical organizations to maintain healthy leadership because they are unable to convince lower members to ascend the leadership ranks and take charge of the organization. Clancy, a former commander in the Chicago Police Department, described how, in the past, gang leaders could make credible threats to keep their gangs on the street in order:

It used to be like that. The Jeff Forts of the world. The guy we're still talking about 20 years [later]; these guys have been out ... How long has Jeff Fort been out of commission? Gino Colón, Gino's been in jail for 25 years. He's the head of Latin Kings, Northside Latin Kings. We're still talking about those same guys because no one is really stepping up. No, you wouldn't want to be that guy; you don't want to be "the guy" because you're going to get targeted. Not only by law enforcement but other gang members.

While, undoubtedly, there are clandestine leaders who attempt to manage the organization's interests, their need to be invisible to gang intelligence officers curbs their ability to engage effectively and to maintain the group's numbers through fresh recruitment. While these administrative measures do not eradicate gangs completely, they do decrease the gang's share of the prison protection market. To that end, a sustained and consistent targeting of any and all gang leadership within prison indicates to potential leaders of upstart groups that eventually they will find themselves placed in solitary confinement for the rest of their natural lives. This outcome appears to have a deterrent effect for individuals wanting to become powerful leadership figures given the lack of vertical, upstart groups that have come onto the prison scene in Illinois and Texas over the past 15 years or more.

Instead, in response to leadership targeting, horizontally configured groups have emerged to compete for a share of the protection market, supplanting the dominant vertical groups of before and protecting members from being targets of law enforcement operations and opposing gangs. Horizontally configured groups may have come into their own to compete with vertical groups, may have splintered from existing groups, or may have converted from a vertical structure as a survival strategy.

In Texas, these groups are collectively known as Tangos, a slang term for one's home (Tapia et al. 2014). According to the Texas Department of Public Safety Texas 
Gang Threat Assessments, the Tango cliques are the largest and most rapidly growing "prison gangs" in Texas, collectively totaling more than 15,000 members across all sets (Texas Department of Public Safety 2013, 2014, 2015). The Texas Department of Public Safety, however, does not indicate whether these 15,000 members are of the same gang, working in concert; in fact, many of these cliques may even have conflicts with one another.

My respondents indicated that the Tangos were the result of dissatisfaction with the rules imposed by the established gangs as well as the implausibility of establishing a competing vertical group. The various Tango cliques were able to attract members because of their "lack of delineated hierarchy, lack of constitution/by-laws, no 'bloodin, blood-out' mandate" and the ability to return to their street gangs upon release from custody (Texas Department of Public Safety 2015, p. 35). Their primary role is to provide protection. Joey, a member of Chuco Tango, one of the many Texas Tangos, described his responsibility to his fellow Chuco Tango members as follows: "I'm going to back him up regardless of whatever, and we're going to fix shit between us; even if he's fucking up, I'm going to back him up."

Likewise, in Illinois, the existing People and Folk federations evolved from vertical into horizontal groups within prison once their leadership was systematically targeted by the state. Although the original reasons for the formation of the People and Folk federations are unclear, older gang members described a pattern of splintering and creating competing groups from the 1970s. One such gang member, Doc, evoked the religious metaphor of the fall of Lucifer: "Folks and Peoples: it all started off as one. There was always one. Then you had one person that wanted more than what he was given. He wasn't satisfied. Just like God and the Devil."

Membership within a federation appears to be primarily a function of being incarcerated and the need for protection while incarcerated and holds little importance in the street. Just as in Texas, protection is important for Illinois inmates. Many feel they have no choice but to join an inmate group given the severe disadvantages of attempting to do one's time unaffiliated. Jay, a former GD from Chicago who was a member of the Folk Nation when incarcerated, noted that, if an inmate were a neutron, that is unaffiliated,

you got treated like crap. You got stolen from. People took your food, took your clothes. You didn't have no protection. You was on your own. [...] If me and my group of friends decided to push you around today, then we could push you around today because ain’t no one gonna help and stop you.

In other words, joining a group meant joining a "survival unit," a group that is able to attack enemies and defend against them, operating with much the same logic as that used by a nation-state (Elias 1978).

In both the Illinois and Texas cases, the horizontal groups behave as a cross between what Buentello et al. (1991) describe as "predator groups" and "prison gangs," exhibiting characteristics of both. Horizontal groups act as predator groups in that they have some rules of conduct and will engage in intimidation and retaliation. They act as prison gangs in part because they have well-defined goals - primarily, to provide protection for their members and to eliminate undesirables - and in part because they have an extensive membership, which extends throughout the prison system (Texas Department of Public Safety 2015). 
However, horizontal groups stand apart from vertical groups in that they are flatter in structure which allows them to survive even when their leadership is targeted. These organizations appear to have two tiers of involvement. At the top is leadership, which attempts to maintain a low-key presence and may act as mediators in times of conflict with other groups. Frank, a Juárez based gang member affiliated with Chuco Tango, described the role one of the leaders played in standing up to the Barrio Azteca status quo:

There was no charge, but the head of the Chuco Tango, some guy they called Vargas, he was the head of us, and he had a meeting with the Barrio Azteca and he told them, "You know what? From this day on, we're not going to take orders from you. We are [operating in] our separate ways. We're not affiliated with you in any way at all."

Vargas was stabbed after that stand, and Frank was unsure who the next de facto leader was.

Under the leadership committee, the rest of the Tango is on a relatively even footing, undertaking social control based on availability and proximity to a situation. For instance, Joey, another Chuco Tango member, noted that when a person wanted to join or leave Chuco Tango, he would get "checked out. [...] It's just three homeboys look at you right away," meaning that members of the gang evaluate the qualifications for entry or the reasons for departure.

Frank and Joey's explanations of the group's dynamics illustrate two points. First, members enjoy relative equality among themselves and few, if any, "yard bosses" emerge. When they do, dominant figures appear to have the respect of their peers, but do not seem to institute hierarchy. Accordingly, it is nearly impossible for prison administrators, short of subjecting the entire prison population to solitary confinement, to break a horizontal group. Second, decisions are often made collectively; decisions on who should be included, excluded, and disciplined are done by a group of members who are in proximity to the situation and who are acting on behalf of the entire unit. Consequently, horizontal groups are effective in engaging in collective action, resulting in a maximization of protection within the prison walls while minimizing the threat of having any one member put into solitary confinement.

However, membership in a horizontal group is distinct from vertical groups because even as the group becomes a mature gang within the prison system, lifelong allegiance is not required nor expected (Texas Department of Public Safety 2015). Moreover, once an inmate is released back into the free world, he not only is free to represent his own street gang without fear of reprisal from his prison associates but also has no obligations to his prison gang and its members be they inside or outside prison.

With membership not necessarily transferring its obligations to the street, as would be the case with a vertical group, the protection that horizontal organizations enjoy in prison does not extend to the street and, from what I could observe, did not translate into the underpinnings of illicit enterprise in the free world. For example, the most recently released inmates I interviewed agreed that Barrio Azteca no longer has control over county jails and most prisons. Moreover, its visibility has diminished as a matter of strategy to reduce unwanted law enforcement attention. Nonetheless, Barrio Azteca remains a driving force in the narcotics trade in the Paso del Norte corridor. It is 
possible, however, that the inability of Barrio Azteca to build its ranks via prison, as it has done historically, will force it to fundamentally change how it recruits new members, if it is to survive in the same capacity that it currently does.

In Chicago, where vertical prison hierarchy has long since eroded, there is little consistent cooperation among street gangs; no one has been able to unite the factions under a united front, even within themselves. Officer Banner, a Chicago policeman who works in primarily blighted, African-American parts of the city with high gang activity, described the current situation:

The black gangs are becoming increasingly flat organizations. It's a function of how small the gangs are becoming. Yes, there are historic animosities between groups such as the BDs [Black Disciples] and the GDs. But that's not how conflicts are necessarily drawn today. The [news]paper might report that there are 30,000 GDs, and the reader presumes that there are 30,000 unified members. But the truth is that some of these gang members are friends with one another, but many are not. There are $600+$ gang factions of 50 to 250 individuals, and they mostly beef with ${ }^{5}$ each other at a neighborhood level.

In short, the violent conflicts which continue to affect Chicago negatively today are the result of the number of factions that exist. There are few, if any, standing orders that come from the prisons to dictate the actions of a given faction. In fact, many warring groups may even be part of the same faction but only cooperate when incarcerated; the social control that vertical groups can exert on the streets is not a typical characteristic of horizontal groups, meaning that while prison authorities may have more relative control in prisons, policing bodies may have to deal with more fractionalized criminal groups competing in the free world. Whether this outcome will occur in other areas, such as major Texas cities, where vertical groups are losing their control, remains to be seen.

\section{Conclusion}

In this article, I have shown that the social order in prisons is a function of a protection market. When the state cedes control, historically vertical prison gangs have formed to fill that void. I have expanded on the Buentello et al. (1991) framework by illustrating the set of circumstances that lead to gang development, exhibiting the various types of control shifts that can occur within the prison protection market. To that end, the social organization of prison groups has changed as they have adapted to and been affected by social control interventions by the state and competing groups. These new horizontal groups are flatter, more loosely coupled, and less formally constituted, which makes controlling them, both from outside and from within, almost paradoxically more difficult. Because they have a reach that expands throughout a prison system, these horizontal groups are not merely solidarity groups which fall on the existing Buentello el al. spectrum. Nevertheless, it appears that the "reach" of these new groups is more constrained in terms of the street politics of drug dealing and violence, meaning that the

${ }^{5}$ To beef with someone is to be in conflict with that person. 
social control traditionally affected on the street by vertically configured prison gangs may decay over time, resulting in an increase in violence, as is the case in Chicago.

Given that horizontal groups are relatively new in the American penal system, and that this study, like most to date which have examined prison gangs, has a clear geographical limitation, the generalizability of what is being observed may be limited (Jacobs 1979). Nonetheless, this research indicates that there is a need to examine the emergence of horizontal prison gangs and their impact over time on the social order of prison and on the social order of the criminal underworlds that many of their members return to upon being released from prison.

Acknowledgements I would like to thank Gordon Hughes, Martin Innes, Michael Levi, David Skarbek, participants in the Cardiff Centre for Crime, Law and Justice, and the two anonymous reviewers who gave me valuable comments to improve this work. I would also like to thank the many people at UACJ, UTEP, ASU, and Loyola University Chicago who supported me in this project by providing spaces to interview my respondents and helping with access. I also thank the respondents who participated in this study. This research was approved by the Cardiff University Ethics Committee. The author was funded by the Economic and Social Research Council (ESRC) as a doctoral student and additionally by an ESRC Overseas Research Travel Grant to conduct the fieldwork this work is based upon.

Open Access This article is distributed under the terms of the Creative Commons Attribution 4.0 International License (http://creativecommons.org/licenses/by/4.0/), which permits unrestricted use, distribution, and reproduction in any medium, provided you give appropriate credit to the original author(s) and the source, provide a link to the Creative Commons license, and indicate if changes were made.

\section{References}

Arizona Criminal Justice Commission (2016) 2014 Arizona gang threat assessment. Arizona Criminal Justice Commission, Phoenix

Arizona Department of Corrections (2017) Inmate ethnic distribution by unit. Arizona Department of Corrections, Phoenix

Bowden C (2010) Murder City: ciudad Juárez and the global Economy's new killing fields. Nation Books, New York Buentello S, Fong RS, Vogel RE (1991) Prison gang development: a theoretical model. Prison J 71(2):3-14 Burman ML (2012) Resocializing and repairing homies within the Texas prison system: a case study on security threat group management, administrative segregation, prison gang renunciation and safety for all. (Ph.D.). University of Texas, Austin

Cromwell PF, Olson JN (1991) Breaking and entering: an ethnographic analysis of burglary. Sage, Newbury Park

Decker SH, Pyrooz DC, Sweeten G, Moule RK Jr (2014) Validating self-nomination in gang research: assessing differences in gang embeddedness across non-, current, and former gang members. J Quant Criminol 30(4):577-598

Dilulio JJ (1990) Governing prisons. Simon and Schuster, New York

Dooley BD, Seals A, Skarbek D (2014) The effect of prison gang membership on recidivism. J Crim Just 42(3):267-275

Edwards A, Hughes G (2005) Comparing the governance of safety in Europe a geo-historical approach. Theor Criminol 9(3):345-363

Ekland-Olson S (1986) Crowding, social control, and prison violence: evidence from the post-Ruiz years in Texas. Law Soc Rev 20:389-421

Elias N (1978) What is sociology? (S. Mennell \& G. Morrissey, trans.). Columbia University Press, New York Fischer DR (2001) Arizona department of corrections: security threat group (STG) program evaluation, final report. Retrieved September, 25, 2004

Fleisher MS, Decker SH (2001) An overview of the challenge of prison gangs. Correct Manag Q 5:1-9

Fong RS (1990) The organizational structure of prison gangs: a Texas case study. Fed Probat 54:36

Fong RS, Buentello S (1991) The detection of prison gang development: an empirical assessment. Fed Probat 55:66

Fukuyama F (2013) What is governance? Governance 26(3):347-368 
Gambetta D (1993) The Sicilian mafia: the business of private protection. Harvard University Press, Boston Gundur RV (2017) Using the internet to recruit respondents for offline interviews in criminological studies. Urban Aff Rev. https://oi.org/10.1177/1078087417740430

Hagedorn JM (2006) Race not space: a revisionist history of gangs in Chicago. J Afr Am Hist 91(2):194-208

Heckathorn DD (2002) Respondent-driven sampling II: deriving valid population estimates from chainreferral samples of hidden populations. Soc Probl 49(1):11-34

Hunt G, Riegel S, Morales T, Waldorf D (1993) Changes in prison culture: prison gangs and the case of the "Pepsi generation". Soc Probl N. Y. 40:398-398

Irwin J (1980) Prisons in turmoil. Little, Brown and Company, Boston

Jacobs JB (1979) Race relations and the prisoner subculture. Crime Justice 1:1-27

Justice WW (1981) Consent decree in the matter of Ruiz v. Estelle, Jr.: U.S. District Court, Southern District of Texas

Marquart JW, Crouch BM (1984) Coopting the kept: using inmates for social control in a southern prison. Justice Q 1(4):491-509

Orlando-Morningstar D (1997) Prison gangs. Spec Needs Offender Bull 2:1-13

Pyrooz D, Decker S, Fleisher M (2011) From the street to the prison, from the prison to the street: understanding and responding to prison gangs. J Aggress Conflict Peace Res 3(1):12-24

Reuter P (1983) Disorganized crime: illegal markets and the mafia Disorganized crime: The economics of the visible hand. MIT Press, Cambridge

Sampson RJ (2012) Great American City: Chicago and the enduring neighborhood effect. University of Chicago Press, Chicago

Skarbek D (2010) Putting the "con" into constitutions: the economics of prison gangs. J Law Econ Org 26(2): $183-211$

Skarbek D (2011) Governance and prison gangs. Am Polit Sci Rev 105(04):702-716

Skarbek D (2014) The social order of the underworld: how prison gangs govern the American penal system. Oxford University Press, Oxford

Tapia M, Sparks CS, Miller JM (2014) Texas Latino prison gangs: an exploration of generational shift and rebellion. Prison J 94(2):159-179

Texas Department of Criminal Justice (2017) Statistical report: fiscal year 2016. Texas Board of Criminal Justice, Austin

Texas Department of Public Safety (2007) Texas gangs: an overview of security threat groups and other major gangs in Texas. The Texas Department of Public Safety, Criminal Intelligence Service

Texas Department of Public Safety (2013) Texas gang threat assessment 2012. Texas Department of Public Safety, Austin

Texas Department of Public Safety (2014) Texas gang threat assessment. Texas Department of Public Safety, Austin Texas Department of Public Safety (2015) Texas gang threat assessment. Texas Department of Public Safety, Austin The Illinois Department of Corrections (2017) Fiscal year 2016 annual report. Illinois Department of Corrections, Springfield

Thompson EP (1966) History from below. Times Literary Supplement 7(04)

Thrasher FM (1927 [1963]) The gang: a study of 1,313 gangs in Chicago (J. J. F. Short Jr Ed. abridged ed.). University of Chicago Press, Chicago

Tilly C (1985) War making and state making as organized crime. In: Evans PB, Rueschemeyer D, Skocpol T (eds) Bringing the state back in. Cambridge University Press, Cambridge

Trammell R (2012) Enforcing the convict code: violence and prison culture. Lynne Rienner Publishers, Boulder U.S. Census Bureau (2016) QuickFacts beta Retrieved from https:/www.census.gov/quickfacts

Wright RT, Decker SH, Redfern AK, Smith DL (1992) A snowball's chance in hell: doing fieldwork with active residential burglars. J Res Crime Delinq 29(2):148-161 